UDC 621.391 .6

\title{
REQUIREMENTS FOR OPTICAL TRANSPORT NETWORKS FOR SUCCESSFUL IMPLEMENTATION OF 5G TECHNOLOGY
}

\author{
Olena G. Grygorenko, Galyna D. Sozonnik \\ Institute of Telecommunication Systems \\ Igor Sikorsky Kyiv Polytechnic Institute, Kyiv, Ukraine
}

Background. The amount of data generated, transmitted and accumulated in the world is constantly growing every year. On the other hand, users need new services and information exchange capabilities. 5G technology is able to meet the requirements of subscribers to some extent. Therefore, it is important to consider the main features of fifth generation mobile networks and to determine the requirements for the design of optical transport networks that will ensure the successful implementation of $5 \mathrm{G}$ technology.

Objective. The aim of the paper is to determine the features of design and characteristics of optical transport networks to implement the capabilities of $5 \mathrm{G}$ technology.

Methods. The analysis of the publications devoted to modern optical networks and their optical components allowed defining the basic requirements to design of optical transport networks and their characteristics.

Results. It is established that optical transport networks should provide increased bandwidth; possibility of mass optical cross-connections in ROADM/OXC nodes that support addition/removal of any wavelength from/in any direction; intelligent operation and maintenance of the network.

Conclusions. The defined requirements for the design of optical transport networks and their characteristics will ensure the successful implementation of the capabilities of 5G technology, which will meet the needs of subscribers.

Keywords: $5 \mathrm{G}$ technology; optical fiber; ROADM; OXC.

\section{Introduction}

The amount of data generated, transmitted and accumulated in the world is constantly growing every year. The Internet of Things (IoT), Big Data, artificial intelligence and other innovations are fast becoming realities of modern life. Storage of data in cloud storage and operation of applications in the cloud environment are used today. According to forecasts the number of devices connected to the Internet could reach 50 billion at any time, starting in 2025 [2]. Powerful transport networks are needed to transmit such an ever-increasing amount of data. Existing optical transport networks support a wide range of communication services, including mobile services.

On the other hand, users need new services and information exchange capabilities. $5 \mathrm{G}$ technology is able to some extent meet the requirements of subscribers to the growing amount of data transmitted and the introduction of new services. Use in the mobile network of systems with spaced transmitting and receiving antennas (MIMO Multiple Input Multiple Output), providing multiple input/output, and applications such as cloud radio access network (C-RAN - Cloud-Radio Access Networks) and Coordinated multi-point (CoMP), which requires low latency and precise synchronization, results in a high throughput requirement.

Therefore, it is important to consider the main features of the fifth generation of mobile networks and to determine the requirements for the design of optical transport networks that will ensure the successful implementation of $5 \mathrm{G}$ technology.

\section{Requirements for the implementation of $5 \mathrm{G}$ technology}

The fifth generation of mobile technology (5G) is expected to bring people, IoT, data, applications, smart transport systems and cities together in a smart network environment. They need to transmit a huge amount of data much faster, provide a reliable connection to a huge number of devices and process very large amounts of data with minimal delay. [2]

$5 \mathrm{G}$ technologies are expected to support applications such as smart homes and buildings, smart cities, 3D video, cloud work and play, remote medical services, virtual and augmented reality, and mass machine-to- machine interconnection for production automation. [2]

It is envisaged that $5 \mathrm{G}$ will provide faster data transfer than $4 \mathrm{G}$, will make it possible to place devices with higher density, and provide opportunities for direct interaction between different devices.

Among other things, the $5 \mathrm{G}$ standard should provide the following characteristics $[8,10]$ :

o peak data download speed per base station up to 20 Gbps;

- data download speed up to $100 \mathrm{Mbit} / \mathrm{s}$ and download up to $50 \mathrm{Mbit} / \mathrm{s}$ for one subscriber; 
○ the ability of the subscriber unit to move at speeds up to $500 \mathrm{~km} / \mathrm{h}$ between base stations;

0 the ability of devices to switch in $10 \mathrm{~ms}$ between energy saving mode and fully operational;

$\circ$ delays of up to $4 \mathrm{~ms}$ under favorable conditions, and up to $1 \mathrm{~ms}$ for specialized connections;

○ improved efficiency of radio frequency spectrum use;

- Data transfer at $1 \mathrm{Gbps}$ at the same time for many users on one floor of the building;

o the ability to operate up to 1 million devices per $1 \mathrm{~km}^{2}$ [8].

$5 \mathrm{G}$ communication uses two ranges of electromagnetic waves - FR1 (600-6000MHz) and FR2 (24-100GHz).

\section{Requirements for the characteristics of optical transport networks}

The first commercial network of the fifth generation was launched in October 2018, when the telecom operator Verizon announced the launch of "the world's first $5 \mathrm{G}$ network" in four US cities: Houston, Indianapolis, Los Angeles and Sacramento [11].

Globally, the fifth generation wireless technology $(5 \mathrm{G})$ will be launched in the current 2020 [1]. The optical network that will provide $5 \mathrm{G}$ technology must meet the three main characteristics without which full operation is not possible, namely:

- enhanced transmission capacity of the optical fiber;

- massive optical cross-connections;

$\circ$ intelligent operation and maintenance of the network.

When providing the above characteristics, the network will have the main functions, as illustrated by the triangular diagram for $5 \mathrm{G}$ (Fig. 1):

- enhanced broadband mobile communication;

- massive machine type communication;

- ultra-reliable and low latency communication.

These three main features together support an expanded range of services and are compatible with the new services that will appear in the $5 \mathrm{G}$ era. It will also support the transmission of the growing IoT traffic.

To meet the requirements of advanced $5 \mathrm{G}$ broadband, optical networks must provide greater bandwidth and be costeffective [4].

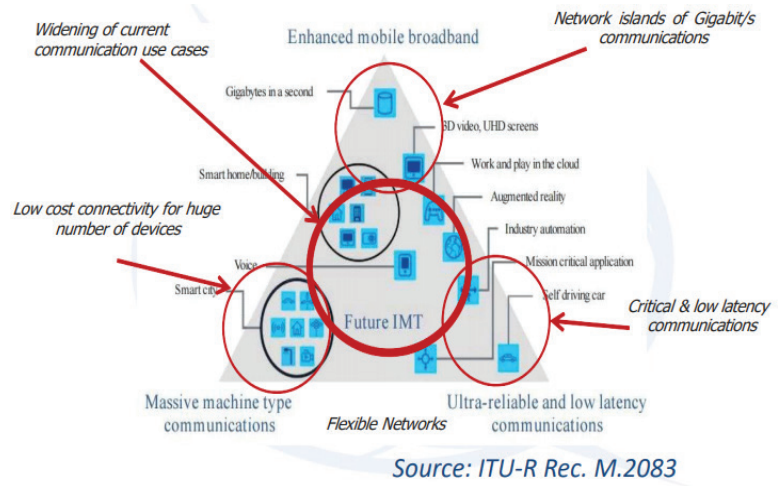

Fig.1 The main functions of 5G networks [3]
During the period 2013-2019, the bandwidth of the optical fiber increased from $8 \mathrm{Tbit} / \mathrm{s}$ to $32 \mathrm{Tbit} / \mathrm{s}$ [1]. In 2013, digital coherent detection with SD-FEC (soft-decision forward-error correction) allowed to transmit channels at a speed of $100 \mathrm{Gbps}$ with quadrature phase manipulation and polarization division multiplexing of the optical signal (PDM-QPSK - Polarization-division multiplexing quadrature-phase-shift keying) at a distance of more than $4000 \mathrm{~km}$.

EDFA amplifiers used in optical networks provide in the C-band (1530-1565 nm, ie amplification bandwidth $4 \mathrm{THz})$ transmission of eighty optical channels in the one optical fiber at a speed of $100 \mathrm{Gbps}$ with a step between channels of $50 \mathrm{GHz}$, which leads to the throughput of each fiber 8 Tbit $/$ s, today - 32 Tbit / s. Thus, the spectral efficiency of the WDM (Wavelength division multiplexing) system was 2 bits / s / Hz, which in 2019 increased to 5.3. Optoelectronic devices using 32 Gbaud for modulation / demodulation provide $128 \mathrm{Gbps}$ data rate for PDM-QPSK and $100 \mathrm{Gbps}$ data rate after deletion of service data for FEC (Forward Error Correction). Higher level quadrature amplitude modulations (QAM), such as the PDM-64QAM, have been introduced to further increase speeds, for 2019 the speed of optoelectronic devices is 64 Gbaud. Digital processing of optical signal was based on 40-nm CMOS-technology, today - 7-nm CMOS-technology, in the future 5-nm CMOStechnology is expected [1].

In the future, using both the extended C-band and the extended L-band, the EDFA gain band may be increased to $10 \mathrm{THz}$ and beyond. With advances in optoelectronic device technology, the modulation rate can exceed 100 Gbaud. More advanced digital optical signal processing algorithms include probabilistic constellation shaping (PCS) for higher-level QAM, nonlinearity compensation, and co-processing of superchannel components [9] that can be implemented using 5-nm CMOS technology. When these characteristics are achieved in 2022, data transmission systems will further double the capacity of optical fibers to $64 \mathrm{Tbit} / \mathrm{s}$ [1].

Fig. 2 shows the measured spectrum of 195 optical channels placed in increments of $50 \mathrm{GHz}$, with a spectral efficiency of $10.3 \mathrm{bps} / \mathrm{s} / \mathrm{Hz}$ and a total EDFA gain of 9.75 $\mathrm{THz}$, which gives a capacity of one optical fiber $100.5 \mathrm{Tbit} / \mathrm{s}$ $[1,7]$. The transmission path consisted of six segments of 100-kilometer fiber corresponding to G.654E. The amplification of EDFA in the C- and L-bands was used. 


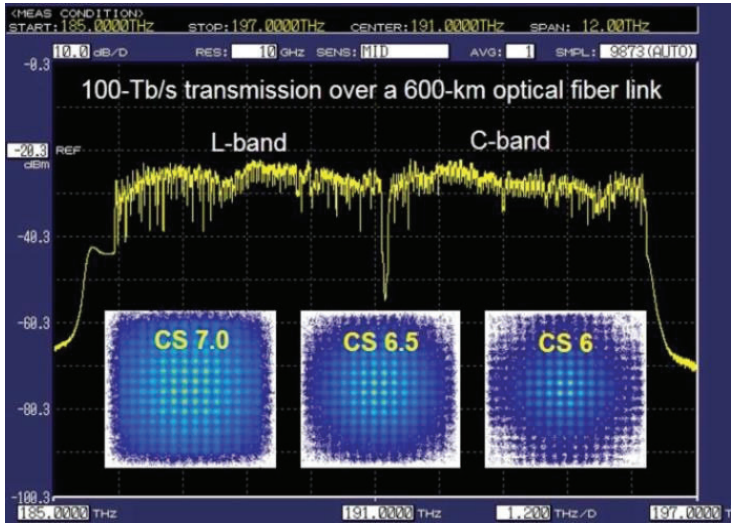

Fig.2 Measured spectrum of 195 optical channels transmitted by one optical fiber at a distance of $600 \mathrm{~km}$, which shows the capacity $100.5 \mathrm{Tbit} / \mathrm{s}$ [1]

When using 5G, long delays in the network are unacceptable, as technologies and applications are sensitive to delays and are highly dependent on data transmission rates. Therefore, it is necessary to transport WDM systems channels with low delay, to use optical cross-connections as much as possible to switch optical channels of different wavelengths, which will provide direct connections at the optical level through different nodes of 5G-oriented optical networks.

Massive optical cross-connections are required to provide full switching capability for all WDM channels in all fibers connected to the optical node. This can be achieved by using multidegree reconfigurable nodes of optical channels addition/dropping (MD-ROADM - multi-degree reconfigurable optical add / drop multiplexer) and optical cross-switching components (OXC - optical cross-connect).

\section{Design features of optical transport networks}

As mentioned, optical transport networks (OTNs) use Dense Wavelength Division Multiplexing (DWDM) technology, which allows efficient use of optical fiber bandwidth by increasing as needed the number of optical channels (wavelengths) transmitted in one optical fiber. The main nodes of such a network are DWDM terminal nodes, where a multi-channel DWDM signal is formed / terminated, reconfigurable nodes of optical channels addition/dropping (ROADM), optical channel cross-connect nodes (OXC) and optical amplification nodes.

Multidegree ROADM and optical cross-connect (OXC), which are supposed to provide mass optical crossconnections in 5G networks, are built using wavelength selective switch (WSS) and wavelength cross-connect (WXC). One of the options for WSS design is an optical multiplexer and demultiplexer based on the arrayed waveguide grating technology (AWG), between which for each wavelength is an optical switch that either blocks a given wavelength without passing it from the demultiplexer to the multiplexer, or passes it to the multiplexer. Instead of blocked wavelengths, new optical channels are added in their place to form a new multi-channel DWDM signal.

Fig. 3 illustrates a ROADM / OXC node that supports adding / removing any wavelength from / to any direction.

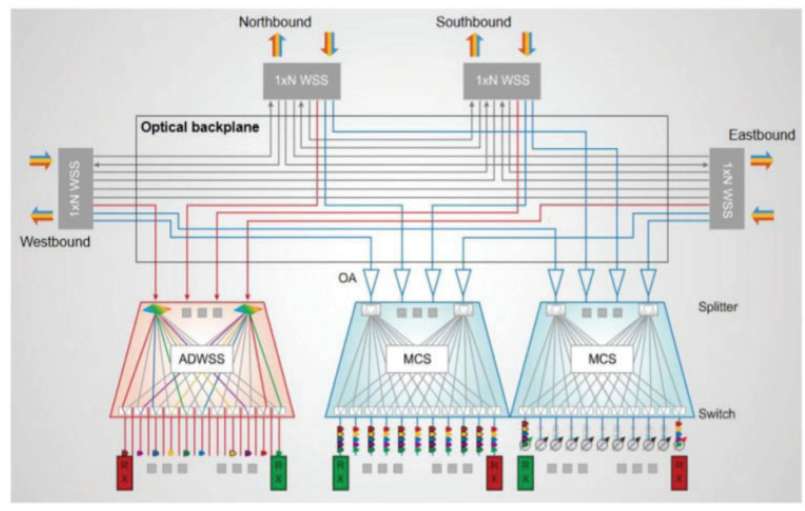

Fig.3 Example of a node ROADM/OXC [1]

(ADWSS - Add/Drop WSS, MCS - Multi-cast Switch )

Since optical multiplexing / demultiplexing is performed by passive elements, it is necessary to take into account the optical power loss using optical amplifiers. Typically, the insertion loss per optical multiplexing / demultiplexing operation is 5-7 dB. EDFA optical amplifiers have a wide gain band, C-band - 1530-1565 nm or L-band - 1565-1625 $\mathrm{nm}$, and can increase the power of the multi-channel DWDM signal by 17-34 dB. In addition to EDFA amplifiers, Raman amplifiers are also used, which use the effect of Raman scattering in optical fiber.

In addition to optical amplifiers, chromatic dispersion compensation units are used to increase the length of regeneration sections in the optical transport network. Also at transmission speeds greater than $10 \mathrm{Gbps}$ in the optical channel, it is necessary to take into account the presence of polarization mode dispersion (PMD) in the optical fiber. Modern methods of optical signal modulation and the use of digital coherent receivers (DCR - Digital Coherent Receiver) with optical digital signal processors [1] makes it possible to fully compensate for chromatic dispersion and PMD using linear digital filters in the electromagnetic field reconstruction by DCR receiver. This allows to get today the transmission data rate at a wavelength of $100 \mathrm{Gbps}$ and above.

As an example, in the Cisco Systems' ONS 15454, which is widely used in Ukrainian telecommunications networks, the 15454-OPT-EDFA-24 enhanced C-band amplifier card [12] does not use an intermediate stage to connect chromatic dispersion compensation units (DCUs). This has been made possible by using of coherent detection technology and a new PM-DQPSK modulation format in the 40 and 100 Gbps transponder units, which eliminates the need for dispersion compensation. In addition, the noise figure of these erbiumdoped fiber amplifiers (EDFA) is optimized by having one gain stage, without an intermediate one - for DCU 
connection. The 15454-OPT-EDFA-24 card can simultaneously amplify up to 96 optical channels with an interchannel interval of $50 \mathrm{GHz}$ in the extended C-band 1528.77-1566.72 nm with the gain of up to $24 \mathrm{~dB}$.

For example, the SMR20-FS and SMR20-FS-CV cards [13] used in Cisco NCS 2000 equipment integrate two optical cross-connect units with multiplexer and demultiplexer, a variable gain EDFA preamplifier, and an EDFA booster. In addition, the SMR20-FS-CV card has a special laser source in the demultiplexer section and a photodiode in the multiplexer section, which provide the ability to check the connection. These cards support up to 20 directions for each ROADM node and are used in different topologies.

The ROADM / OXC subsystem can become more compact by using the integrated $\mathrm{N} \times \mathrm{N} \mathrm{OXC}$ at the wavelength level for line-side switching and the integrated $\mathrm{N}$ $\times$ M WSS for local add/drop connections and fiber-free connections. The new WSS add/drop provides reduced losses and power consumption [5].

To maximum simplify and configure the correct operation of the $5 \mathrm{G}$ network has a system of intelligent network operation and maintenance, which provides the ability of the fast network planning and reliable service. At the stage of operation, traffic forecasting, troubleshooting and error warning are possible. At the optimization stage, adaptive resource management and network slicing partition ensure that the service is supported adequately and with resource efficiency [6]. With the introduction of artificial intelligence in a networked cloud environment, it has become possible to predict failures in optical networks and future requirements for network resources, thus increasing the operation and maintenance efficiency.

\section{Conclusion}

The article considers the main features of the fifth generation mobile communication networks and identifies the requirements for the optical transport networks design that will ensure the successful implementation of 5G technology and new services based on it.

The characteristics of current and future optical transport networks are indicated. It is expected that the optical fiber use efficiency will continue to increase. OTN equipment components will integrate more and more functions, increase their productivity and energy efficiency.

It is concluded that to support $5 \mathrm{G}$ technology, optical transport networks should provide increased optical fiber throughput; mass optical cross-connections based of ROADM / OXC nodes that support the addition / removal of any optical channel from / to any direction; intelligent network operation and maintenance, which provide opportunities for reliable and adaptive resource management.

\section{References}

1. Liu Xiang. Evolution of Fiber-Optic Transmission and Networking toward the $5 \mathrm{G}$ Era/ LIU Xiang// iScience. 2019. - $\quad$ Dec $22 . \quad$ - p p.489-506; https://www.ncbi.nlm.nih.gov/pmc/articles/PMC6920305/

2. $5 \mathrm{G}$ - the fifth generation of mobile communication technology

https://www.itu.int/ru/mediacentre/backgrounders/Pages/5Gfifth-generation-of-mobile-technologies.aspx

3. Marco Carugi. Progress of 5G studies in ITU-T// ITU Regional Forum on "Internet of Things, Telecommunication Networks and Big Data as basic infrastructure for Digital Economy”, Saint-Petersburg, Russian Federation, June 4-6, 2018; $\quad$ https://www.itu.int/en/ITU-T/Workshops-andSeminars/20180604/Documents/Session1.pdf

4. Grigorenko O. Features of implementation of efficient optical transport networks; Bulletin of NTUU "KPI", series "Radio Engineering. Radio Apparatus Building", No. 73, 2018. - pp.28-32

5. Colbourne, Paul D., et al. Contentionless twin $8 \times 24$ WSS with low insertion loss// Optical Fiber Communication Conference. Optical Society of America. - 2018. - Th4A.

6. Vilalta R., López-de-Lerma A.M., Muñoz R., Martínez R., Casellas R. Optical Networks Virtualization and Slicing in the 5G era/ Optical Fiber Communication Conference, San Diego, USA. - 2018. - M2A.4

7. Yu Y., Jin L., Xiao Z., Yu F., Lu Y., Liu L., Wu W., Li L. $100.5 \mathrm{~Tb} / \mathrm{s}$ MLC-CS-256QAM Transmission over $600-\mathrm{km}$ Single Mode Fiber with $\mathrm{C}+\mathrm{L}$ Band EDFA, Asia Communications and Photonics Conference (ACP) PDP Su2C.3; 2018.

8. Sebastian Anthony. 5G specs announced: 20Gbps download, $1 \mathrm{~ms}$ latency, $1 \mathrm{M}$ devices per square $\mathrm{km}$. 2/24/2017; https://arstechnica.com/informationtechnology/2017/02/5g-imt-2020-specs/

9. Chandrasekhar S., Liu X. Advances in Tb/s superchannels, Chapter 3 of Optical Fiber Telecommunications VI. In: Kaminov I.P., Li T., Willner A., editors. Elsevier; 2019. pp. 751-784

10. https://uk.wikipedia.org/wiki/5G\#cite_note-:2-5

11. Zhdanov A. How are $5 \mathrm{G}$ networks evolving in Russia and the world; https://telesputnik.ru/materials/tekhnika-itekhnologii/ article/seti-5g-v-mire-i-v-rossii/

12. https://www.cisco.com/c/en/us/products/collateral/ optical-networking/ons-15454-series-multiservice-transportplatforms/data_sheet_c78-658542.html

13. https://www.cisco.com/c/en/us/td/docs/optical/ $15000 \mathrm{r} 10 \mathrm{0} / \mathrm{ncs} /$ linecard config/guide/b ncs line card conf iguration $/ \bar{b}$ ncs line card configuration chapter $0101 \overline{0} . \mathrm{htm}$ l\#concept_CCFFD01FD0524C51BD29D93968B-̄E4E1 
Григоренко О.Г., Созонник Г.Д.

Вимоги до оптичних транспортних мереж для успішного впровадження технології 5G

Проблематика. Кількість даних, що генеруються, передаються і накопичуються у світі невпинно зростає 3 кожним роком. 3 іншого боку, користувачі потребують нових сервісів та можливостей обміну інформацією. Технологія 5G спроможна в певній мірі задовольнити вимоги абонентів. Тому важливим є розглянути основні особливості мереж мобільного зв'язку п'ятого покоління та визначити вимоги до побудови оптичних транспортних мереж, що забезпечать успішне впровадження технології $5 \mathrm{G}$.

Мета досліджень. Визначення особливостей побудови та характеристик оптичних транспортних мереж для реалізації можливостей технології $5 \mathrm{G}$.

Методика реалізації. Аналіз джерел, присвячених сучасним оптичним мережам та їх оптичним компонентам, дав змогу визначити основні вимоги до побудови оптичних транспортних мереж та їх характеристик.

Результати досліджень. Встановлено, що оптичні транспортні мережі мають забезпечувати збільшену пропускну здатність; можливість масових оптичних крос-з'єднань у вузлах ROADM/OXC, що підтримують додавання/видалення будь-якої довжини хвилі з/в будь-якого напрямку; інтелектуальну експлуатацію та обслуговування мережі.

Висновки. Визначені вимоги до побудови оптичних транспортних мереж та їх характеристики забезпечать успішну реалізацію можливостей технології 5G, що буде відповідати потребам абонентів.

Ключові слова: технологія 5G; оптичне волокно; ROADM; OXC.

Григоренко Е.Г., Созонник Г.Д.

Требования к оптическим транспортным сетям для успешного внедрения технологии 5G

Проблематика. Количество генерируемых, передаваемых и накопленных данных в мире неуклонно растет с каждым годом. С другой стороны, пользователи требуют новых сервисов и возможностей обмена информацией. Технология $5 \mathrm{G}$ способна в определенной степени удовлетворить требования абонентов. Поэтому важно рассмотреть основные особенности сетей мобильной связи пятого поколения и определить требования к построению оптических транспортных сетей, которые обеспечат успешное внедрение технологии $5 \mathrm{G}$.

Цель исследований. Определение особенностей построения и характеристик оптических транспортных сетей для реализации возможностей технологии $5 \mathrm{G}$.

Методика реализации. Анализ всех известных публикаций, посвященных полосовым фильтрам СВЧ на взаимно расстроенных резонаторах в параллельных каналах, позволил выявить присущие им закономерности (типы колебаний в параллельных каналах, расположение полюсов затухания выше или ниже полосы пропускания), проявляющиеся независимо от используемых типов резонаторов.

Результаты исследований. Анализ источников, посвященных современным оптическим сетям и их оптическим компонентам, позволил определить основные требования к построению оптических транспортных сетей и их характеристикам.

Выводы. Установлено, что оптические транспортные сети должны обеспечивать увеличенную пропускную способность; возможность массовых оптических кросс-соединений в узлах ROADM/OXC, поддерживающих добавление/удаление любой длины волны с/на любого направления; интеллектуальную эксплуатацию и обслуживание сети.

Ключевые слова: технология 5G; оптическое волокно; ROADM; OXC. 